\title{
Rural-Urban Linkages: The Case of Rural Migrants from Upper West Region to Obuasi Municipality in the Ashanti Region, Ghana
}

\author{
Hikimatu Lalaki Awudu
}

Email: hikimatu.awudu@stu.ucc.edu.gh

Owusu Boampong

Institute for Development Studies, University of Cape Coast, Cape Coast, Ghana

\author{
Nana Amma Anokye \\ Institute for Development Studies, University of Cape Coast, Cape Coast, Ghana \\ DOI//http://dx.doi.org/10.4314/gjds.v16i3.6
}

\begin{abstract}
In migration studies, research on backward linkages has received a lot of attention. However, research on rural-urban forward linkages is scanty. This article explored the forward linkages from rural households in the Upper West Region of Ghana to urban migrants in the mining town of Obuasi, which has a long history of attracting migrant workers. The study employed a qualitative research design using in-depth interviews to gather data from 26 respondents in Tizza, Kojokpere, Issa, Kaleo and Jang; and 13 urban migrants in Obuasi. Four focus group discussions were conducted in Obuasi to support and validate the in-depth interviews conducted in the rural communities. The study shows that the resource flows from Tizza, Kojokpere, Issa, Kaleo and Jang to urban migrants in Obuasi are in the form of social support, financial and food transfers. The rural households view the resource flows as necessary for sustaining the livelihoods of their migrant family members and for maintaining affective ties. The study establishes that reverse flows put financial and social burdens on rural households and this burden drains resources of rural households.
\end{abstract}

Keywords: Forward Linkages, Livelihood Strategy, Migrants, Obuasi, Upper West Region

\section{INTRODUCTION}

People migrate for various reasons. They may do so as part of their efforts to improve the livelihoods of their families, learn new skills, to acquire new experiences, to find 
a job or to run away from unsafe conditions such as insecurity, disaster or famine (Ito, 2010). Tanle (2003) argues that migrants use the strategy of moving out as a response to better economic and non-economic opportunities and an expectation of increased economic welfare of households. Rural-urban migration is a strategy in which economic and social links between migrants and their rural households are maintained (Steinberg, 2014). This strategy may not be the outcome of an individual migrant's decision but could be a conscious strategy of the migrant's household to diversify household income sources and become less vulnerable to shocks, risks or local constraints (Ellis, 200o). The rural household decision to send a member to an urban area is based on the consideration of the benefits of migration (such as remittance flows, higher local incomes and the mitigation of risks) and the costs of migration comprising travelling costs and the lack of farmhands at home (Lindley, 2008).

Several studies on migration have focused on the flows of resources and support from urban migrants to rural household members, which are often referred to as backward linkages (Adjei, 2016; Ellis, 2000; Lindley, 2008; Tanle \& Abane, 2016; Yaro, 2008). There are few studies that have focused on the flows of resources from household members at the rural places of origin to migrants' relatives at specific urban destinations (forward linkages) (Frayne, 2007; Mobrand, 2012; Scully, 2012; Tanle \& Abane, 2016). Tanle and Abane (2016) recommended further studies into the forward linkages existing between migrants and their rural place of origin in Ghana. This was especially so, as their study which solicited the views of urban migrants identified child fostering as the only type of forward linkage. According to Mobrand (2012) the forward linkage dimension of migration, which is also referred to as reverse remittance is under-researched and least appreciated by policymakers and international development institutions. Accordingly, this paper examined the forward linkages from rural households to urban migrants. This study did not only seek the views of urban migrants but also the perspectives of family members at the rural places of origin.

Most development theories and practices have focused on either "urban" or "rural" issues with little consideration of the interrelations between the two (Steinberg, 2014; Tacoli, 1998a; Tacoli \& Mbala, 2010). This study proceeded on the basis that the two locations are intertwined and family members in both locations depend on each other for support. In this case, the construction of household/family traverses the rural setting to encompass urban destination of migrant families. The household comprises members in the rural and urban areas and as such, depend on each other for support. This is reinforced by Tacoli's (1998a) view that since links 
are maintained by rural families and urban migrants, households can be described as multi-spatial.

The connection between the Upper West Region and Obuasi municipality has existed from the colonial period to present day in Ghana. The British colonial state required then Northern Territories to send labourers to southern areas to ensure the plantations, mines and other labour-intensive sectors of the colonial economy had the required labourers available. An agreement between the then annexed Northern Territories (NT) and the Gold Coast government, formalised the forced labour migration in 1901 in Ghana (Lentz, 2006). After the abolition of the forced labour in 1936, household members continued to migrate to the southern part of Ghana till date. It is worthy of note that labourers from the Upper West region, formerly part of the NT were mostly sent to Obuasi. According to AbdulKorah (2007), the Upper West and the Obuasi connection is due to internal factors specifically related to the Upper West Region. Van der Geest (2011a) and Primavera (2005) noted poor climatic conditions as one of the factors responsible for voluntary movement by the people of the Upper West region to Obuasi.

Other studies suggest that urban migrants maintain strong links and other personal networks in their rural places of origin to survive in the urban environments (Abdul-Korah, 2007; Dungumaro, 2013; McDowell \& de Haan, 1997; Tanle, 2014; van der Geest, 2011a). The connections range from food support, financial remittances to visits to the rural place of origin for various reasons such as funerals (AbdulKorah, 2007). Studies that have studied linkages between urban centres and rural areas highlight the flows embedded in such linkages to include the movement of people, goods, capital and other social transactions (Tacoli, 1998b). These play a significant role in the livelihood of both rural and urban households (Tacoli, 1998a).

\section{LITERATURE REVIEW}

\section{Concept of Livelihoods and Livelihood Diversification}

How people make their living is a question that has been debated by various scholars since the 1970's (Sakdapolrak, 2014). Livelihoods research gained focus and prominence in the late 1980's when researchers more fully explored the definition and concept of livelihoods. Ellis (2000) defined this concept by stressing on access to assets and activities that are informed by social relations (gender, class, kin and belief systems) and institutions. Scoones (2009: 173) distinguishes the concept of livelihood from other concepts as an "integrative, locally embedded, cross sectorial [concept] informed by deep field engagement and a commitment to action." From 
these definitions, a livelihood can be understood as explaining how people combine different resources and activities to live.

According to Scoones (1998), the strategies households adopt in order to survive can be grouped into three categories: (1) livelihood diversification, (2) migration and (3) interventions. However, for the purpose of this study, the focus will be on the first two categories. Diversification, the first category, can be described as a survival strategy for households and individuals who need to resort to different activities to minimise risks and make ends meet. Migration, the second category, is explained as a social process, where households construct a diverse portfolio of activities to make a living. In this sense, migration is seen as a livelihood strategy. In the case of reverse resource flows from rural families to urban migrants, such flows serve as "emergency reserve" or survival strategy for the urban migrants (Kruger, 1998). Migration as a source of diversified livelihood is favoured as conceptual framework because the transformations in the ways in which households and individuals make a living are the most striking aspect of rural-urban linkages, and in many cases involve multiple occupations ranging from farming and services to processing and manufacturing.

\section{Migration and Rural-Urban Forward Linkages}

Scholarly works on migration point to the effect of remittances from migrants on the development of rural places of origin (Martin, 1993; Mobrand, 2012; Stark, 1980). The developmental perspective of migration is hinged on the very idea that households encourage members to migrate as a strategy to diversify income sources as insurance against uncertainties and shocks (Ellis, 2000, van der Geest, 2010). Family members who migrate to cities continue to maintain strong links and other personal networks in their areas of origin (Adjei, 2016). Household and community incomes of families who have relatives away from home have been found to expand because of remittances sent back home (Tanle \& Abane, 2016).

According to Yaro (2008), remittances are in fact the "livewire" linking migrants to their families in their home villages and most rural people, for whom agriculture is no longer a secured source of livelihood, depend to some extent on remittances for survival. However, Mobrand (2012) has challenged this benign perspective of the contribution of remittances to the development of rural places of origin and noted that in South Korea, the reverse is the case. In South Korea, Mobrand (2012) observed a net flow of remittances from rural places of origin to cities and urban centres. The reverse resource transfers were in cash and they were done to meet living expenses of migrants, pay school fees of migrant children, and meet medical expenses. This led him to question the real developmental effect of remittances to 
sending villages by stating that: “...because remittances serve as an important link between migration and development, the finding of significant reverse remittances challenges leading ideas on how migration can assist development in sending regions" (Mobrand, 2012: 390).

Some studies have examined the phenomenon of reverse flows of resources from rural households to migrant families in urban centres (Frayne, 2007; Mobrand, 2012). Scully (2013) examined the strategies that households who have their wageearning members in urban areas and non-wage-earning members in rural areas undertake to survive. He observed that black South African wage-earning family members in urban South African settings heavily depended on non-wage-earning family members in their rural homes for support. The support was in the form of urban migrants sending their children to be cared for by the rural family so that these urban migrants can have time for their jobs at the urban centers.

Similarly, Frayne (2007), observed the existence of close and complex social connections between rural and urban family members in Windhoek, Namibia, which makes it possible for households to endure economic difficulties' in times of scarce employment opportunities in the formal urban economy. He concluded that the main survival strategy employed by urban family members in lieu of regular formal employment is the production and provision of food by the rural areas. Kruger (1998) also observed that migrants in Gaborone, Botswana maintained strong connection with their rural villages to enable them deal with problems of income and food insecurity in the monetised urban setting. In this instance, rural assets served as a safety reserve for the urban poor. The migrants in the city fell on goats, cows, grains and vegetables produced in the villages as emergency reserve in times of economic difficulties.

In the specific context of Ghana, Tanle and Abane (2016) examined the forward and backward linkages between migrants at their destinations (in the southern part of Ghana), and household members in the three northern regions of Ghana (places of origin) and how such interactions contribute to poverty reduction in the three northern regions. Their study established forward linkage between close relations in the three northern regions and migrants at their destinations. They noted that while rural family members send their children to the urban migrants to be cared for, and for formal education and skills training, the children assist the migrants in their businesses and housework. 


\section{METHODOLOGY}

\section{Study Areas}

The research was conducted in three districts (Jirapa, Daffiama-Bussie-Issa and Nadowli-Kaleo) of the Upper West Region and in the Obuasi Municipality in the Ashanti Region in Ghana. The Upper West Region shares a common border with Burkina Faso in the west and north, the Upper East Region in the east and with the Northern Region in the south. The climatic condition of the region is made up of dry (harmattan) season and wet (rainy) season. The wet season usually starts from early April and ends in October. The Upper West Region is considered an agricultural risk zone because the Sahara Desert is advancing into the region. The rainfall variability and precipitation are not ideal for agriculture without irrigation. This means that the people living in the region need to be very innovative to survive. According to Primavera (2005), any negative human activity on the ecology of the region, can reduce agricultural production. Research indicates that migration, both seasonal and permanent, is a central element of rural livelihoods in this region (van der Geest 2011b).

The Obuasi Municipality is in the south-western part of the Ashanti Region. The municipality is endowed with mineral deposits that makes gold mining the most profitable economic activity in the area. Mining and its related activities form the backbone of the municipal economy. The possibility of work in the mining sector has made Obuasi one of the popular destinations for migrants especially from the Upper West Region. The percentage of inhabitants that are migrants in the municipality is $46.1 \%$ (Ghana Statistical Service, 2014). By the mid twentieth century, official estimates showed that people from northern Ghana accounted for 19 per cent of the total work force at the Obuasi mines and 27 per cent of those working underground (Lentz, 2006). As noted earlier, the connection between the Upper West Region and Obuasi has existed from the colonial period to present day, hence the selection of the two locations for the study.

\section{Data and Methods}

This study adopted qualitative approach and used in-depth interviews to seek perceptive information from 26 and 13 respondents in some selected communities in Upper West Region and urban migrants in Obuasi in the Ashanti Region respectively. Snowball strategy was used to obtain an interconnected network of migrants in Obuasi and their relatives in the selected rural communities in the Upper West Region. The research team visited Obuasi in August 2016 to obtain preliminary information about the existing linkages between migrants from Upper 
West who are resident in Obuasi and their relatives in their rural places of origin. The respondents selected for the study were heads of migrant households and/or returned migrants. The interviews took place in the following rural areas in Upper West Region: Tizza in Jirapa District; Kojokpere and Issa in Daffiama-Bussie-Issah District; and Kaleo and Jang in Nadowli-Kaleo District. In the end, 26 respondents were interviewed.

An in-depth interview with individual migrants in Obuasi who had received some support from their rural places of origin in Upper West Region was conducted. These individuals were purposively selected for the interviews and they included 7 males and 6 females. Four focus group discussions (FGDs) were organised with migrantbased associations at different localities (Boete, Tutuka, Brahabebome, Koffikrom/ Gausu) where the migrants are concentrated. Common trends were identified from the data and grouped into themes based on the research questions. Concepts discussed in the literature review served as the primary guide for analysis. Thick description was used in the discussion of the results.

\section{RESULTS AND DISCUSSION}

\section{Social Support, Food and Financial Transfers for Maintaining Livelihood of Urban Migrants}

This section discusses the forward rural-urban linkages between urban migrants in Obuasi and their rural place of origin in the Upper West Region. Three key resource flows were identified in the study. These were social support, food and financial transfers from the rural households in the areas in Upper West Region to their migrant relatives in Obuasi. Social support comprised assisting with female reproductive roles, contributions toward and attendance of marriage and funeral ceremonies. Financial transfers are meant for the daily upkeep of the recipient, payment of educational expenses of wards and one-off payments for contingencies. Food transfer which took the form of food gift occurred for three reasons. First, as an expression of affective ties between the rural household sender and the migrant recipients; second, it helps the migrant recipients to satisfy their cravings for the long-lost local delicacies and third reduces the recipient migrants' expenditure on food purchases. These resource flows demonstrate the motive of forward rural and urban linkages. The flows and rural-urban linkages are also explained within the migration-livelihood framework as not only for survival motive in the urban setting (Scully, 2012 \& Frayne, 2007) but also for socio-cultural and affective reasons. 


\section{Social Support for Urban Relatives in Birth, Marriage and Death}

With respect to social support, family members visit the urban areas to help nursing mothers to take care of their new-born babies. There were instances when rural households mobilise resources and select some family members to visit the urban centre to help take care of the new-born baby and the nursing mother. Table 1 summarises the types of social support provided by rural relatives in the Upper West Region (UWR) to migrant relatives in Obuasi. Table 1 shows that the main types of social support are given at the time of birth, marriage, sickness and death. 
Table 1: Types of social support given to urban relatives in times of need

\begin{tabular}{|c|c|c|c|c|c|}
\hline & & $\begin{array}{l}\text { Birth \& female } \\
\text { reproductive } \\
\text { roles }\end{array}$ & Marriage & Sickness & Funeral \\
\hline \multicolumn{6}{|c|}{ Senders } \\
\hline \multicolumn{6}{|c|}{ Rural place of Origin (UWR) } \\
\hline Community & District & & & & \\
\hline Jang & $\begin{array}{l}\text { Nadowli- } \\
\text { Kaleo }\end{array}$ & $\begin{array}{l}\text { Assist nursing } \\
\text { mother to take } \\
\text { care of newborn } \\
\text { baby. }\end{array}$ & $\begin{array}{l}\text { Provide money, } \\
\text { goat. }\end{array}$ & $\begin{array}{l}\text { Contribute to } \\
\text { hospital bills. }\end{array}$ & $\begin{array}{l}\text { Perform final } \\
\text { funeral rites. }\end{array}$ \\
\hline Kaleo & $\begin{array}{l}\text { Nadowli- } \\
\text { Kaleo }\end{array}$ & $\begin{array}{l}\text { Help in naming } \\
\text { ceremony. Assist } \\
\text { nursing mother to } \\
\text { take care of new } \\
\text { born baby. }\end{array}$ & $\begin{array}{l}\text { Provide money. } \\
\text { Represents the } \\
\text { family during } \\
\text { marriage } \\
\text { ceremony. }\end{array}$ & $\begin{array}{l}\text { Contribute } \\
\text { to hospital } \\
\text { bills. Spiritual } \\
\text { treatments. }\end{array}$ & $\begin{array}{l}\text { Perform the } \\
\text { final funeral } \\
\text { rites. Provide } \\
\text { locally brewed } \\
\text { gin (Pito). }\end{array}$ \\
\hline Kojokpere & $\begin{array}{l}\text { Daffiama- } \\
\text { Bussie-Issah }\end{array}$ & $\begin{array}{l}\text { Help in the } \\
\text { naming ceremony. }\end{array}$ & $\begin{array}{l}\text { Provide cattle. } \\
\text { Provide money. }\end{array}$ & $\begin{array}{l}\text { Hospital bills, } \\
\text { spiritual \& } \\
\text { traditional } \\
\text { treatments. }\end{array}$ & $\begin{array}{l}\text { Perform the } \\
\text { final funeral } \\
\text { rites at the } \\
\text { place of } \\
\text { origin. }\end{array}$ \\
\hline Issa & $\begin{array}{l}\text { Daffiama- } \\
\text { Bussie-Issah }\end{array}$ & $\begin{array}{l}\text { Assist nursing } \\
\text { mother to take } \\
\text { care of newborn } \\
\text { baby. }\end{array}$ & $\begin{array}{l}\text { Provide money, } \\
\text { goat }\end{array}$ & $\begin{array}{l}\text { Spiritual \& } \\
\text { traditional } \\
\text { treatments. }\end{array}$ & $\begin{array}{l}\text { Perform the } \\
\text { final funeral } \\
\text { rites. }\end{array}$ \\
\hline Tizza & Jirapa & $\begin{array}{l}\text { Assist nursing } \\
\text { mother to take } \\
\text { care of a newborn } \\
\text { baby. Take care of } \\
\text { the aged return } \\
\text { migrant family } \\
\text { members. }\end{array}$ & $\begin{array}{l}\text { Provide money, } \\
\text { prepare locally } \\
\text { brewed gin } \\
\text { (Pito). }\end{array}$ & $\begin{array}{l}\text { Traditional } \\
\text { and spiritual } \\
\text { treatments. } \\
\text { Assist in } \\
\text { taking care of } \\
\text { a sick relative. }\end{array}$ & $\begin{array}{l}\text { Transport the } \\
\text { deceased body } \\
\text { to the place } \\
\text { of origin. } \\
\text { Perform final } \\
\text { funeral rites } \\
\text { at the place of } \\
\text { origin. }\end{array}$ \\
\hline \multicolumn{6}{|l|}{ Recipients } \\
\hline Obuasi & $\begin{array}{l}\text { Urban } \\
\text { destination }\end{array}$ & $\begin{array}{l}\text { Receive assistance } \\
\text { with baby care. }\end{array}$ & $\begin{array}{l}\text { Receive } \\
\text { assistance in } \\
\text { preparation } \\
\text { of wedding } \\
\text { ceremony; } \\
\text { represent } \\
\text { family head } \\
\text { during the } \\
\text { ceremony, } \\
\text { provide money. }\end{array}$ & $\begin{array}{l}\text { Receive } \\
\text { assistance in } \\
\text { seeking for } \\
\text { traditional } \\
\text { and spiritual } \\
\text { treatments. }\end{array}$ & $\begin{array}{l}\text { Receive } \\
\text { assistance } \\
\text { in burying } \\
\text { the dead and } \\
\text { performing } \\
\text { final funeral } \\
\text { rites of } \\
\text { deceased. }\end{array}$ \\
\hline
\end{tabular}

Source: Field data, 2016/2017 
In support of this, a female respondent in Kojokpere for example iterated that "My stepson's wife has given birth, and we are likely to go to Obuasi tomorrow to help them with the naming ceremony... My husband will not go, but it is going to be myself and the stepson's mother." Responses from the FGDs and interviews by the urban migrants in Obuasi also confirmed that relatives from the rural areas visited them whenever they had new-born babies. A respondent in Obuasi said:

You know these young women when they give birth, they cannot take care of the [newborn] baby especially when it is their first time.... when my wife gave birth, my mother had to come down from the village to help her take care of the baby.

The female relations (i.e. mothers and mothers-in-laws) in rural Upper West were those who visited to help them take care of the new-born babies and perform other reproductive roles for their relations in the urban area. These female relations are mostly the elderly people who possess rich experience in reproductive roles.

It was also evident that Obuasi migrants received support during marriage ceremonies. When a respondent in Kojokpere was asked about the support he gives to his household in times of need, his reply was that "For marriages I either provide cow depending on the number of cattle I have at the time of the occasion or money." Rural family members do provide support to their urban relatives in the event of sickness or death. The Dagaares, like other ethnic groups in Ghana, prefer to be buried in their hometown when they die. This is because the rural relations provide financial and non-financial support in the burial ceremony in the hometown. It shows that urban migrants from Upper West Region are connected to their rural place of origin even in death. Regarding sickness, a respondent at Tizzaa noted that sick urban migrants are mostly brought to their rural homes to seek alternative methods of treatment which included spiritual and traditional forms of healing in cases where in their view orthodox forms of treatment prove to be inefficacious.

The varied connections between the rural respondents and the urban migrants buttress Tacoli's (1998a) interpretation that viewing rural populations and activities separately from urban ones is misleading because the two locations are often related across geographic space and development sectors. For instance, one finds a rural dweller offering their unpaid reproductive service to an urban migrant family member. Similarly, Akkoyunlu (2015) stated that there is a strong interrelationship and any transformation or change in sectors affects rural and urban areas in proportion to their interrelatedness. Urban migrants benefit socially from their rural place of origin and therefore to say that urban migrants live in isolation from their rural counterparts is a parody of reality. 


\section{Financial Transfers for Household Living Expenses}

One of the supports revealed in the study was transfer of finance for the upkeep of relatives in Obuasi. Respondents in rural UWR indicated supporting family members who are living in Obuasi financially. Table 2 summarises the different purposes for sending financial support by rural relatives at UWR to urban migrants at Obuasi. These monies were mostly sent by parents, extended family members and siblings for the payment of school fees and upkeep of the migrant family in Obuasi. This is shown by Table 2 which also indicates that monies sent as one-off payments were mostly for training as apprentice in a trade. These results are buttressed by the quotations that follow.

Table 2: Purposes of financial support given to urban relatives

\begin{tabular}{|c|c|c|c|c|}
\hline & & Daily upkeep & $\begin{array}{l}\text { Payment of } \\
\text { educational } \\
\text { expenses of } \\
\text { wards }\end{array}$ & $\begin{array}{l}\text { One-off payments } \\
\text { (Proxy payment) }\end{array}$ \\
\hline \multicolumn{5}{|l|}{ Senders } \\
\hline \multicolumn{5}{|c|}{ Rural place of Origin (UWR) } \\
\hline Community & District & & & \\
\hline Jang & $\begin{array}{l}\text { Nadowli- } \\
\text { Kaleo }\end{array}$ & $\begin{array}{l}\text { Upkeep of brothers, } \\
\text { sisters, nephews and } \\
\text { cousins. }\end{array}$ & $\begin{array}{l}\text { Payment of school } \\
\text { fees. }\end{array}$ & $\begin{array}{l}\text { Financial } \\
\text { contribution to send } \\
\text { off a family member } \\
\text { to an urban area to } \\
\text { start a new life. }\end{array}$ \\
\hline Kaleo & $\begin{array}{l}\text { Nadowli- } \\
\text { Kaleo }\end{array}$ & $\begin{array}{l}\text { Upkeep of wife and } \\
\text { children. }\end{array}$ & $\begin{array}{l}\text { Payment of school } \\
\text { fees. }\end{array}$ & $\begin{array}{l}\text { Payment of } \\
\text { apprenticeship } \\
\text { training. }\end{array}$ \\
\hline Kojokpere & $\begin{array}{l}\text { Daffiama- } \\
\text { Bussie-Issah }\end{array}$ & $\begin{array}{l}\text { Upkeep of wife and } \\
\text { children. }\end{array}$ & $\begin{array}{l}\text { Payment of school } \\
\text { fees. }\end{array}$ & $\begin{array}{l}\text { Selling cow and using } \\
\text { proceeds to help a } \\
\text { daughter boost her } \\
\text { business. }\end{array}$ \\
\hline Issa & $\begin{array}{l}\text { Daffiama- } \\
\text { Bussie-Issah }\end{array}$ & $\begin{array}{l}\text { Upkeep of wife and } \\
\text { children. }\end{array}$ & $\begin{array}{l}\text { Payment of school } \\
\text { fees. }\end{array}$ & $\begin{array}{l}\text { Payment of } \\
\text { apprenticeship } \\
\text { training in mechanics. }\end{array}$ \\
\hline Tizza & Jirapa & $\begin{array}{l}\text { Upkeep of son and } \\
\text { brother. }\end{array}$ & $\begin{array}{l}\text { Payment of school } \\
\text { fees. }\end{array}$ & $\begin{array}{l}\text { Payment of } \\
\text { apprenticeship } \\
\text { training in tailoring. }\end{array}$ \\
\hline \multicolumn{5}{|l|}{ Recipients } \\
\hline Obuasi & $\begin{array}{l}\text { Urban } \\
\text { destination }\end{array}$ & $\begin{array}{l}\text { Receive money } \\
\text { for upkeep of } \\
\text { unemployed }\end{array}$ & $\begin{array}{l}\text { Payment of school } \\
\text { fees. }\end{array}$ & $\begin{array}{l}\text { Receive money to } \\
\text { train as a hairdresser. } \\
\text { Payment for village } \\
\text { chief funeral. }\end{array}$ \\
\hline
\end{tabular}

Source: Field data, 2016/2017 
A returned male migrant in Kojokpere remarked: "I sent my wife and children money for school fees and upkeep". Similarly, a male respondent from Tizzaa had this to say:

My son lives with my elder brother and his wife in Obuasi...So after bumper harvest, I sell some of the foodstuff and send the money to them...It is not good for you ... [to push your burden] on somebody like that without helping. It would be like you are irresponsible and not showing appreciation.

The story was not different for returned pensioners who had family members living in Obuasi. They mentioned sending money to their children and wives whenever they received their monthly pension. For instance, a male pensioner in Issa indicated that:

I send money to my wife in Obuasi. You know my mother-in-law stays with her and the children... The burden is sometimes heavy on her... At the end of the month when I receive my pension I support her by sending her some money.

Another retired returned migrant reported that his wife and children did not return with him from Obuasi to the UWR. He stated that "When my wife is hardup financially, I sometimes help her to pay the children's school fees." Another pensioner at Kaleo said "No matter how small my monthly pension is, I have to send some to my wife to take care of our children and this sometimes stresses me financially." Discussions from the FGDs and the individual interviews with migrants living in Obuasi confirmed that these urban migrants received monetary support from relatives at their places of origin.

The reverse financial transfers from rural family members to urban migrants are similar to the findings of Mobrand (2012) in South Korea. Mobrand (2012) established that the reverse resource transfers were in cash and they were done so to meet living expenses of migrants, pay school fees of migrant children, and meet medical expenses. This, in the view of Mobrand, challenges the benign developmental impact of remittances on the sending regions. The reverse flow of financial resources to urban migrant members places a heavy burden on the less resourceful rural relatives because the conditions for which monies are sent to urban members do not matter whether the sender is wealthy or not. Some family members transferred monies to their migrant relations because they felt it was their social obligation to do so, even when no financial request had been made. 
Others also sent monies to their urban relatives because they were in dire need of financial support. The respondents from Obuasi corroborated receiving financial assistance from their relations in the rural areas. A female respondent in Obuasi confirmed receiving money from her mother to help cater for her essential needs such us toiletries, among others because she was unemployed. This respondent lives with the elder sister whose husband is a small-scale miner. Unfortunately, the sister's husband had had his income source curtailed due to government of Ghana's restrictions on small-scale mining, hence her reliance on her mother in the village for financial support.

Money sent on one-time basis for a particular expense was also found in this study. A respondent in Kojokpere explained he had to sell a cow and send the proceeds to his daughter in Obuasi. He explained that the daughter requested for it to expand her business and he had to help. Scully (2013) described this one-off payment for major expenses as proxy payment. He observed that black South African wageearning family members in urban South African settings heavily depended on nonwage-earning family members in their rural homes for support. However, this study noted that urban migrant members relied on rural family members for support irrespective of whether they were wage-earners or not.

\section{Food Transfers to Sustain Affective Ties and Satisfy Cravings for Local Delicacies}

Most of the heads of households and returned migrants interviewed in the UWR indicated sending food items to their relations in Obuasi. The foods ranged from seasonal food crops, leafy vegetables from wild plants and locally processed foods such as shea butter ${ }^{4}$, dawadawa ${ }^{5}$ (a spice), and dried and/or smoked chicken and guinea fow $l^{6}$. The seasonal food crops include maize, millet ${ }^{7}$, groundnuts ${ }^{8}$, cowpea beans ${ }^{9}$, Bambara beans ${ }^{10}$, and local rice. The female respondents in a FGD in Obuasi stated that even tuvfaa [a rare type of wild plant used for soup] they send it to us. Some of the other vegetables are baobab ${ }^{11}$ leaves, beng vaa (cowpea beans leaves),

\footnotetext{
Scientific name for shea butter is Vitellaria paradoxa

Scientific name fordawadawa is Parkia biglobosa.

Scientific name for guinea fowl is Numididae

Scientific name for millet is Pennisetum species

Scientific name for groundnuts is Arachis hypogaea

Scientific name for cowpea beans is Vigna unguiculata

Scientific name for bambara beans is Vigna subterranean

1 Scientific name for baobab leaves is Adansonia digitata
}

GJDS, Vol. 16, No. 3, October, 2019 | 121 
bre vaa (kenaf ${ }^{12}$ leaves), and your vaa (pumpkin ${ }^{13}$ leaves). These are food items that are culturally identified with the people of UWR. Groundnuts were either sent when freshly harvested, dried or in the form of a paste. Beef, mutton and chevon were sometimes sent dried, smoked or fried. Table 3 shows the three main types of food support sent by rural relatives in UWR to their migrant relatives in Obuasi. The Table shows that there are three main types of food that are sent to the migrants.

Table 3: Types of food support sent to urban relatives

\begin{tabular}{|c|c|c|c|c|}
\hline & & $\begin{array}{l}\text { Seasonal food } \\
\text { crops }\end{array}$ & $\begin{array}{l}\text { Leafy } \\
\text { vegetables }\end{array}$ & $\begin{array}{l}\text { Locally processed } \\
\text { foods }\end{array}$ \\
\hline \multicolumn{5}{|l|}{ Senders } \\
\hline \multicolumn{5}{|c|}{ Rural place of Origin (UWR) } \\
\hline Community & District & & & \\
\hline Jang & Nadowli-Kaleo & $\begin{array}{l}\text { Maize, millet, } \\
\text { groundnuts, cowpea } \\
\text { and bambara beans, } \\
\text { and local rice. }\end{array}$ & $\begin{array}{l}\text { Baobab, cowpea } \\
\text { beans, kenaf and } \\
\text { pumpkin leaves. }\end{array}$ & $\begin{array}{l}\text { Shea butter, dawadawa, } \\
\text { groundnut paste, dried } \\
\text { and/or smoked chicken } \\
\text { and guinea fowl. }\end{array}$ \\
\hline Kaleo & Nadowli-Kaleo & $\begin{array}{l}\text { Maize, groundnuts, } \\
\text { beans, yam, millet, } \\
\text { local rice. }\end{array}$ & $\begin{array}{l}\text { Dried baobab, } \\
\text { black eyed } \\
\text { beans, kenaf and } \\
\text { pumpkin leaves. }\end{array}$ & $\begin{array}{l}\text { Shea butter, dawadawa, } \\
\text { maize flour, groundnut } \\
\text { paste, dried and/or } \\
\text { smoked guinea fowl. }\end{array}$ \\
\hline Kojokpere & $\begin{array}{l}\text { Daffiama- } \\
\text { Bussie-Issah }\end{array}$ & $\begin{array}{l}\text { Maize, groundnuts, } \\
\text { bambara beans, yam, } \\
\text { millet, local rice. }\end{array}$ & $\begin{array}{l}\text { Dried okro, black } \\
\text { eyed beans and } \\
\text { kenaf leaves. }\end{array}$ & $\begin{array}{l}\text { Shea butter, Dawadawa, } \\
\text { groundnut paste, dried } \\
\text { and/or smoked guinea } \\
\text { fowl, beef and mutton. }\end{array}$ \\
\hline Issa & $\begin{array}{l}\text { Daffiama- } \\
\text { Bussie-Issah }\end{array}$ & $\begin{array}{l}\text { Groundnuts, cowpea } \\
\text { and bambara beans, } \\
\text { yam, millet. }\end{array}$ & $\begin{array}{l}\text { Kenaf and } \\
\text { pumpkin leaves. }\end{array}$ & $\begin{array}{l}\text { Shea butter, Dawadawa, } \\
\text { dried and/or smoked } \\
\text { guinea fowl. }\end{array}$ \\
\hline Tizza & Jirapa & $\begin{array}{l}\text { Groundnuts, maize, } \\
\text { cowpea and bambara } \\
\text { beans, millet, local } \\
\text { rice. }\end{array}$ & $\begin{array}{l}\text { Dried kenaf, } \\
\text { pumpkin and } \\
\text { beans leaves, } \\
\text { Tuvfaa. }\end{array}$ & $\begin{array}{l}\text { Shea butter, dawadawa, } \\
\text { millet flour. } \\
\text { Dried and/or smoked } \\
\text { chicken and guinea fowl. }\end{array}$ \\
\hline \multicolumn{5}{|l|}{ Recipients } \\
\hline Obuasi & $\begin{array}{l}\text { Urban } \\
\text { destination }\end{array}$ & $\begin{array}{l}\text { Maize, millet, } \\
\text { groundnuts, cowpea } \\
\text { and bambara beans, } \\
\text { local rice, yam. }\end{array}$ & $\begin{array}{l}\text { Tuvfaa, dried } \\
\text { baobab, cowpea } \\
\text { beans, kenaf and } \\
\text { pumpkin leaves, } \\
\text { pounded dried } \\
\text { okro. }\end{array}$ & $\begin{array}{l}\text { Shea butter, dawadawa, } \\
\text { maize and/or millet } \\
\text { flour, groundnut paste } \\
\text { Dried and/or smoked } \\
\text { guinea fowl, beef, } \\
\text { mutton and chevon. }\end{array}$ \\
\hline
\end{tabular}

Source: Field data, 2016/2017

12 Scientific name for kenaf leaves is Hibiscus Cannabinus

13 Scientific name for pumpkin leaves is Telfairia occidentalis 
In terms of the pattern of food transfers from the rural areas to the urban centres, regular as well as irregular patterns were observed. The regular pattern of food support occurs every year at the end of each harvest season. To buttress this point, a female respondent had this to say: "We have got nothing to give them all year round because we are poor... but whatever we get after the farming season we give them some too." Additionally, a returned migrant in Kojokpere said, "I can't even count the number of times I send the food to them... because whenever they call that they want food, I send."

When food supports are sent once in two years or even less, then this is referred to as irregular food support. Respondents in rural Upper West who are within this category indicated sending these food supports to urban family members to keep family bonds or show concern occasionally. Others also indicated giving support (in the form of food items) to urban family members when urban members visit them or when they visit them in Obuasi. For instance, a respondent said, "I only send them food when I am visiting them. You know you can't go there empty handed."

In the case of South Africa, food gifts are presented to show love, concern and care for members living in urban areas irrespective of their wealth and status (Scully, 2013). Similarly, the rural family members in UWR send foodstuff for affective reasons and for the urban migrant relatives to satisfy their cravings for traditional delicacies. They send food to maintain family ties and to express care. A returned migrant in Kojokpere said,

I send these things to him [son who lives in Obuasi] even when I don't have enough because I have to show that I care... so that one day when I am no more, he will say he once had a father who cared about him. A returned migrant in Jang said, Money is not a problem for my brothers and sisters in Obuasi... because they are all businessmen and women but they are my siblings, so I have to send them something [foodstuffs] so that they will know that I care.

However, this observation differs from Gaborone, Botswana where food transfers from the villages to the city was considered as emergency reserve for urban migrants facing economic difficulties (Kruger, 1998)

Other rural members felt they had to maintain family ties by reciprocating the good gestures of their urban relatives. For instance, a retiree from Tizza remarked that, "I have to send them something because they are my brothers and they have been sending me money." Another respondent stated that the reason he cares for his brother living in Obuasi is that, "whatever I eat, my younger brother should also eat some... that is why I have to send him some food." 
Correspondingly urban members also received foodstuffs from their rural members as a sign of receiving love from their rural family members. In all the interviews and FGDs conducted in Obuasi the respondents indicated that the food they received implied the existence of care and love between them and their rural family members. "When I received things from them it tells me how caring they are. It is because of love they sent these things [foodstuffs]" (FGD discussant, Obuasi). A respondent from the FGD further reiterated that "...it shows some love and togetherness; although we have left them back home, they miss us and remember us. It makes you feel happy." These examples illustrate the point that family members maintain kinship ties, show care and support to their urban family members through food transfers.

The rural members felt that their migrant family members crave for the local delicacies from their home villages. "They miss eating these delicacies, so we send it to them for them to also enjoy" said by a respondent from Tizza. Another reiterated, "sometimes they come back home to visit because of the foodstuffs. So, it is my responsibility to give them the foodstuffs." Visiting family members in the rural areas for foodstuffs after migrating can be explained as a survival strategy employed by urban migrants to minimise risk and supplement the cost of living.

Respondents in Obuasi confirmed that receiving foodstuffs from their rural family members is indeed beneficial to them. They explained it quenches their craving for food delicacies in Upper West Region.

The FGDs and individual interviews of migrants in Obuasi reinforced the existence of affective ties between them and their rural family members through food transfers. Table 4 captures the views of the migrants during the FGDs on the affective dimension of food transfers and their cravings for traditional delicacies from rural UWR. Not only is food transfer done for the maintenance of livelihood of the urban migrants, but it is also an expression of cultural ties between family members at distant places. 
Table 4: Views of focus group discussants in Obuasi on food transfers

\begin{tabular}{|c|c|}
\hline Affective meaning of food transfer & $\begin{array}{l}\text { Satisfying the cravings of traditional } \\
\text { delicacies }\end{array}$ \\
\hline $\begin{array}{l}\text { - It is because of love they sent these things } \\
\text { - } \quad \text { Toodstuffs] } \\
\text { miss us } \\
\text { - It shows some love and togetherness that } \\
\text { although we have left them back home } \\
\text { they still remember us ... it makes you } \\
\text { feel happy } \\
\text { It indicates some brotherly love amongst } \\
\text { us. It makes us remember that we } \\
\text { still have that brotherly love amongst } \\
\text { ourselves especially, with respect to the } \\
\text { upbringing of our children...They give } \\
\text { the guinea fowl and tell you to use it to } \\
\text { prepare food for the children. It teaches } \\
\text { the children that they have grandparents } \\
\text { [back home] who show care and love even } \\
\text { though they are not together. It makes } \\
\text { you really happy and you feel so loved }\end{array}$ & $\begin{array}{l}\text { - Sometimes you don't get local fowl and } \\
\text { groundnuts to eat. So, you enjoy it when it is } \\
\text { [sent] to you } \\
\text { - Sometimes too you crave for this TZ } \\
\text { [tuozaafi] and tuvfaa soup but you can't get } \\
\text { tuvfaa here you know, so when they send it } \\
\text { to you, that day... hey - you feel you are in } \\
\text { heaven. You put some pepper and small salt } \\
\text { hhmm... } \\
\text { We are used to eating local fowl and it has } \\
\text { been a while since we ate some because they } \\
\text { are not easy to find here. When they send it } \\
\text { to us, hhmm.... we really enjoy it. Sometimes } \\
\text { too we even forget how fresh groundnuts } \\
\text { taste like especially the kids who are born } \\
\text { here; some of them have never tasted fresh } \\
\text { groundnuts ... So when we receive it here, the } \\
\text { children know and understand that, this is } \\
\text { something from home that they have been } \\
\text { missing. } \\
\text {... ahh the guinea fowls are always delicious. } \\
\text { Sometimes when you feel like eating guinea } \\
\text { fowls, then you know you have missed home. }\end{array}$ \\
\hline
\end{tabular}

Source: Field data, 2017.

Besides the affective reason, the respondents in Obuasi noted that the food stuffs they received from their rural family members helped to reduce the financial burden on them in terms of food purchases. For instance, a focus group discussant in Obuasi stated "...when they send me these stuffs it helps... it helps my livelihood/ welfare ... [by] reducing expenses.” Another female FGD discussant added that:

When I visited my relations back home and I returned, I told my husband this is what they gave me. You see, my husband was happy because he knew it would help him. When I cooked the beans, it was enough to feed my entire household. There was no need to buy food for that day.

Some male respondents shared similar view of the financial benefit of food transfers. In one of the FGDs, a discussant commented "When we receive the food, I stop giving chop [upkeep] money. Another added you reduce it [upkeep money]." The local delicacies are rare and expensive in Obuasi, and therefore it is considered cheaper for urban relations to receive food stuffs from their rural place of origin than to buy them in Obuasi. "At that place [Obuasi] our local delicacies are costly, 
but at home it is cheaper. So, we prefer to send it to them", remarked a district assembly worker from Tizzaa. The assertions of the urban migrants are consistent with Frayne's (2007) study in Namibia where the receivers of food transfers acknowledged that it helped them survive in the urban areas.

The fact that food transfers supplement the food needs of urban relations by rural family members can serve as an incentive for household members to migrate in future. Also, the support resulting from the connection between rural families and their urban migrants can be used as a lesson for current migrants to maintain kinship ties with their rural families. Urban migrants will be encouraged to keep these ties with their rural family members because these bonds can serve as a medium of insurance and safety net against unforeseen shocks in the urban areas,

\section{CONCLUSIONS}

The paper explored forward linkages between rural UWR and urban migrants in Obuasi from the viewpoints of both senders and migrant recipients of the resources. Three key resource flows were identified in the study. These included social support, financial flows and food transfers from the rural households to the urban relatives. Rural household members felt socially obliged to send these resources to maintain cultural and affective ties with their urban relatives (in the case of food transfers) though it puts stress on their resources at times. In this regard, the reverse flow of resources from rural areas to urban settings is not only motivated by survival strategies but also for affective reasons.

Instead of the one-sided reading of the benefits that accrue to rural households from their migrant relations in urban centres, this study has revealed that urban migrants do benefit from resource flows from their families in rural place of origin and in some respect, rural households subsidise the lifestyle of their urban migrant relatives.

It is an established knowledge that rural households receive support from their migrant relations in the form of remittances (this has been indicated early in the paper), however, emerging studies on this subject also support a reverse flow of resources from rural relations to urban migrants (this has also been indicated early in the paper). This connection between the rural respondents and the urban migrant family members is consistent with Tacoli's (1998a \& 2002) view that rural populations and their activities are inseparable from urban ones: the two locations are often related across geographic space. Households do not live bounded by geographic areas but have strong bonds with family members who live in different areas. Both rural and urban activities are interlinked and family members in both 
locations depend on each other for support. This study agrees with Akkoyunlu (2015) who believes that there is a strong interrelationship between rural and urban family members and that any change in their economic and social circumstance affects them according to the proportion of their interrelatedness.

Over the decades, much research effort and policy attention have been devoted to migrant remittances and development, especially how remittances contribute to the development of villages of origin (Martin, 1993). This is not always the case as there are reverse remittances that could drain the resources of rural places of origin. This study suggests the need for researchers and policy makers to pay equal attention to the reverse flow as it could be a drain on the resources of rural places of origin and can affect the development of the rural places of origin.

\section{ACKNOWLEDGMENTS}

The authors acknowledge funding from the International Centre for Development and Decent Work (ICDD), University of Kassel, Germany for the data collection. Our thanks go to the Centre for Gender Research, Advocacy and Documentation (CEGRAD), University of Cape Coast, Ghana for the unwavering support rendered to us throughout the data collection process.

\section{REFERENCES}

Abdul-Korah, G.B. (2007). 'Where is not home?': Dagaaba migrants in the Brong Ahafo Region, 1980 to the present. Oxford University Press on behalf of The Royal African Society, 106(422), pp. 71-94.

Adjei, J. (2016). Male out-migration and remittances for households left behind in Northern Ghana. Global Journal of Interdisciplinary Social Sciences, 2, pp. 12-19.

Akkoyunlu, S. (2015). The potential of rural-urban linkages for sustainable development and trade. International Journal of Sustainable Development \& World Policy, 4(2), pp. 01-41.

Dickson, K.B. and Benneh, G. (1988). A new geography of Ghana. UK: Longman Group Limited.

Dungumaro, E.W. (2013). Consequences of female migration for families in Tanzania. African Review of Economics and Finance, 5(1), pp. 45-59.

Ellis, F. (2000). The determinants of rural livelihood diversification in developing countries. Journal of Agricultural Economics, 51(2), pp. 289-302. 
Frayne, B. (2007). Migration and the changing social economy of Windhoek, Namibia. Development Southern Africa, 24(1), pp. 91-108.

Ghana Statistical Service. (2013). 2010 Population and Housing Census: National Analytical Report. Ghana: Ghana Statistical Service.

Ghana Statistical Service. (2014).2010 population and housing census: District analytical report. Obuasi municipality. Ghana statistical service.

Ito, C. (2010). The role of labor migration to neighboring small towns in rural livelihoods: A case study in Southern Province, Zambia. African Studies Quarterly, 12(1), pp. 45-73.

Kruger, F. (1998). Taking advantage of rural assets as a coping strategy for the urban poor: The case of rural-urban interrelations in Botswana. Environment and Urbanization, 10(1), 16.

Lentz, C. (2006). Ethnicity and the making of history in Northern Ghana. Edinburgh: Edinburgh University Press Ltd.

Lindley, A. (2008). The early morning phone call: Remittances from a refugee diaspora perspective. Centre on Migration, Policy and Society. Oxford: University of Oxford, 2007.

Martin, P. (1993). Trade and migration: NAFTA and agriculture. Washington, D C: Institute for International Economics

McDowell, C. and de Haan, A. (1997). Migration and sustainable livelihoods: a critical review of the literature. IDS Working Paper 65.

Mobrand, E. (2012). Reverse remittances: Internal migration and rural-to-urban remittances in industrialising South Korea. Journal of Ethnic and Migration Studies, 38(3), pp. 389-411.

Primavera, C. (2005). Rural - rural migration in Ghana the effects of out-migration on the sustainability of agriculture in the Upper West Region Ghana. Amsterdam: Universiteit Van Amsterdam.

Sakdapolrak, P. (2014). Livelihoods as social practices - re-energising livelihoods research with Bourdieu's theory of practice. Geographical Helvetica, 69, pp. 19-28.

Scoones, I. (2009). Livelihoods perspectives and rural development. The Journal of Peasant Studies, 36(1), 171-196.

Scoones, I. (1998). Sustainable rural livelihoods: a framework for analysis. IDS working paper, 72.

Scully, B. (2012). Land, livelihoods, and the decline of work: South African lessons for current debates. Journal of World Systems Research, XVIII(1), pp. 90-102. 
Scully, B. (2013). Development in the age of wagelessness: Labour livelihoods and thedDecline of work in South Africa. Baltimore, Maryland: Johns Hopkins University.

Steinberg, F. (2014). Rural - Urban linkages: An urban perspective. Working Group: Development with Territorial Cohesion, Working Paper Series $\mathrm{N}^{\circ}$ 128. Santiago, Chile: Territorial Cohesion for Development Program Rimisp.

Stark, O. (1980). On the role of urban-to-rural remittances to Rural Development. Journal of Development Studies, 16(3), pp. 369-374.

Tacoli, C. (1998a). Beyond the rural urban divide. Environment and Urbanization, 10(1), pp. 3-4.

Tacoli, C. (1998b). Bridging the divide: Rural-urban interactions and livelihood strategies. IIED.

Tacoli, C. (2002). Changing rural-urban interactions in Sub-Saharan Africa and their impact on livelihoods: A summary. Working Paper Series on Rural-Urban interactions and livelihood strategies. Working Paper 7, International Institute for Environment and Development (IIED), UK

Tacoli, C., and Mabala, R. (2010). Exploring mobility and migration in the context of rural urban linkages: why gender and generation matter. Environment \& Urbanization, 22(2), pp. 389-395.

Tanle, A. (2003). The movement of female kayaye from northern to southern Ghana. Journal of Arts and Social Sciences 6, pp. 33-41.

Tanle, A. (2014). Assessing livelihood status of migrants from northern Ghana resident in the Obuasi Municipality. Geo Journal, 79(5), pp. 577-590.

Tanle, A. and Abane, M.A. (2016). Forward and backward linkages as poverty reduction strategy in Northern Ghana: A case study of migrants' resident at both the Obuasi and Techiman Municipalities.

van der Geest, K. (2010), Local perceptions of migration from Northwest Ghana. Africa 8o(4), pp. 595-619.

van der Geest, K. (2011a). The Dagara farmer at home and away: migration, environment and development in Ghana. Amsterdam Institute for Social Science Research (AISSR). The Netherlands: African Studies Centre.

van der Geest, K. (2011b). North-South migration in Ghana: What role for the environment. International Migration, 49(SI), pp. 69-94.

Yaro, J.A. (2008). Migration in West Africa: Patterns, issues and challenges. Centre for migration studies, University of Ghana, Accra, Ghana. 